\title{
The Cultivation of Indonesia's Education Financing Policy in Disruption Era
}

\author{
Steaven Octavianus \\ STT-Sangkakala Getasan Kab. Semarang, Indonesia \\ e-mail: stev.oct@gmail.com; \\ \#Corresponding Author \\ Whatsapp Number $\{+62-82221586907\}$
}

\section{ARTICLE HISTORY}

Received: 23 March 2019

Revised: 25 April 2019

Accepted: 20 June 2019

Copyright ( 2019 Authors \& Published by IIES Independent. This is an open-access article distributed under the terms of the CC-BY-SA License.

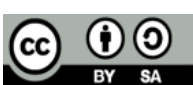

\section{ABSTRACT}

This study is aimed at analyzing the development of education financing policy in Indonesia with the necessity of Indonesia's people. The policy regarding to education financing has long been formulated in Indonesia. Nevertheless how about with its necessity with Indonesian people, it will be analysed trough this research. This research is using text analisis and it only analyzes the policy and law regarding to education financing based on the necessity of Indonesian people. Based on this research it was found that the regulation keeps growing in disruption era but it does not specifically regulate the existing problems in society.

Keywords: Education Financin; Disruption; Indonesian's Necessity

How to Cite: Octavianus, S., (2019). The Cultivation of Indonesia's Education Financing Policy in Disruption Era. International Journal of Advances in Social and Economics, 1(1), 16-21.

\section{Introduction}

Indonesia is one of countries that has the highest population density. According to okezone.com, Indonesia placed 4th as one of the countries with highest population in the world after Chinese, India, and United States (rhs, 2018). Based on these ratings, it can be stated that Indonesia has a lot of Human Resources (HR). Moreover, based on the data and analysis of Bappenas, in 2030-2040 Indonesia will achieve a condition called the demographic bonus (Afandi, 2017). The demographic bonus is a condition where the population of people in productive age (1564 years) is greater than people in non-productive age (under 15 years and over 64 years). Furthermore, Bappenas data showed and estimated that the population of the productive age would reach $64 \%$ of the total population of Indonesia in that bonus demography period.

This prediction is not a mere wishful thinkinglooking at the current condition of the population in Indonesia. Based on the katadata.co.id website, it is known that in 2018 the population in pre-productive age (between 0-15 years) occupies the highest number. Counted from 2018, they will enter productive age for another 12 years. Thus, this will prove the demographic bonus estimation. The existing demographic bonus can be an opportunity or a threat. Demographic bonus can be a threat when productive human resources are no longer productive in work and do not produce anything for themselves or the country. In other words, these HR become unemployed, a burden for the country and the government. However, on the other hand, HR can be a hope and even a golden opportunity for the country. The opportunity means when HR becomes a nonnatural resource that produces something for the nation, productive works or goods that can be used to build the nation and government. This proves that HR is one of the main factors that can determine the progress of the nation (Sutrisnowati \& Hadi, 2002).

In preparing Indonesian human resources to deal with the demographic bonus in this disruption era, HR should be equipped with relevant and qualified education according to the times. With this appropriate education, a country can form a future generation who has the appropriate abilities and generation that can face the challenges before their eyes. This might be a 
factor that makes the demographic bonus as a golden chance and opportunity.

There is one important element in education that can never be ignored. This element is education financing. Education financing is still a crucial issue and an important element for the world of education in Indonesia. This is because Indonesia is, still, a developing country where education funding is not yet $100 \%$ borne by the government. Communities hold a part of responsibilities and bear the costs of education for themselves and the future generations.

Education will not be able to be implemented properly without proper financing, because it is one of the determinants of success in achieving educational goals. Based on this, financing can be a significant problem for the continuity of education in Indonesia, given the paradigm of Indonesian society education is still not a primary need for their lives. On the other hand, education is a future investment in the nation's next generation, thus, public awareness is needed to support this.

In this era of disruption of industry 4.0 revolution, education plays an important role. It is known labor and employment will face very heavy challenges. Based on some future projections there will be a lot of jobs that will be omitted $65 \%$ of the next generation will face the types of jobs that have never been faced before. This means that there will be new work models that have never existed. To deal with these challenges, education is needed to accommodate and prepare for the future ahead.

Talking about the importance of the future, surely education financing will be a determining factor for the success of an educational institution since there will be no implementation without financing. However, if we look at the condition of the Indonesian people's paradigm, it will be very difficult to see education as a top priority due to the fact that many Indonesians still see education merely as an additional need. People are mainly thinking about fulfilling their basic needs. It is understandable for the community to think about this because Indonesia itself is still classified as a developing country where the fulfillment of basic or primary needs is a top priority in the lives of its people.

Looking at those problems, there will be a question about education financing policies in Indonesia. Actually the government does not free itself from the obligation to provide financing in Indonesia since 20\% of the APBN is used in developing the world of education (Fironika, 2015). This shows that the government does not merely let go of its hands in matters of financing education and tauke things for granted.

However, if it is drawn more concisely, there will be a thought about how the development of education financing policies in Indonesia. In response to the problem of financing education in Indonesia, there are various problems in financing education. From the BPS data, it is found that majority of poor students at the district and city levels are vulnerable to be able to continue their education to a higher level (Sinaga, 2017). Furthermore the dropout rate due to poverty according to BPS turned out to reach $73 \%$ in 2016 (Heri, 2016). It is a large number and requires special attention.

Data on the level of continuation of education in Indonesia above shows how close the relationship between financing and Education are. If there is no financing, then education definitely become inapplicable. The data actually shows in the position where our nation is at the level of concern. If in 2030 there will be a surge in population growth in Indonesia and the country still has the same condition (uneducated children), then it will only become a demographic bonus or even a threat to Indonesia. Educated people are not $100 \%$ able to compete in the midst of an era of disruption that is always changing (even in a matter of seconds), let alone those who are not educated. Indeed there are some parties who have no formal education that can survive and develop themselves, like Bill Gates, Steve Job and a number of other wealthy people who didn't pay formal school fees. However not all people could do that since they faced harder and more difficult processes than the process faced by common people.

Looking at this problem, the government certainly has a stake in resolving it. Even though the government has given various policies regarding education financing but there are still many people who still have not fulfilled the minimum compulsory and advanced education, let alone higher education which until now is still seen as a luxury by some elements of society. For this reason, it needs to be studied and examined to what extent the development of education financing policies in Indonesia.

\section{Research Statement}

Based on the problems above, the questions formed underlying this research are formulated: 
How is the development of education financing policies in Indonesia and the congeality with necessity of Indonesian's people?

The formulation of the problem is a guide in this research. Through the formulation of the problem, the objectives of this study are determined. The purpose of this study is to be able to see and describe the development of education financing policies in Indonesia.

If the development of education financing policies is found, alternative proposals can be formulated related to education financing policies in Indonesia in accordance with the factual conditions in the field. Thus the final decision of the policy could be the answer to Indonesia's needs regarding education financing.

\section{Research Method}

This research is using text analysis method. The text that will be analysed is the policy of educational financing in Indonesia. Thus policy will be analysed with the compatibility and necessity of Indonesia's needs.

\section{Education Financing Policy in Indonesia}

\section{Education Financing}

Education financing is a form of financing that is directed as a manifestation of education. Fironika (2015) in its research stated that the components of education funding are operational costs, investment costs and personal costs. These three components are components that make up education funding. This definition was refined in PP No. 32 of 2013 which states that financing is a criterion regarding the components and the amount of operating costs in an education unit for a period of one year.

Based on Government Regulation No. 19 of 2005 operational costs are all costs which include the salary of educators and education personnel, consumable materials or equipment and indirect educational operating costs. Based on this regulation, it can be said that operational costs are all things related to the operational system of an educational institution. It can be said that this operational cost is the main key to whether or not an educational institution can work. For example a salary, if the educator and education staff are not given a salary then of course there will be a work stop. Salaries also have an influence on performance, various studies have proven that salary is one of the main motivational elements that affect one's performance. Disposable equipment also influences the continuity of the education process because without supporting facilities the education process will not work. Indirect operational costs that are rarely considered are also one of the important elements in the operation of education, such as payment of taxes, payment of water and electricity and all kinds of indirect bills and financing.

Furthermore, in the component of investment costs through Government Regulation No. 19 of 2005 it is stated that these costs represent the cost of providing facilities and infrastructure, the development of human resources and permanent working capital. Looking at this exposure, the investment costs are all kinds of costs incurred but will provide beneficial returns in the future. This means that expenditure now will provide something in the future. As for example, the provision of infrastructure is not only for the needs but also for the benefits that can be obtained. Examples of building a hall at school and being able to rent out the hall or with the school hall no longer need another place or rent a place outside the school. Likewise with human development, educational institutions that spend money to develop human beings in this matter are to include various trainings, workshops and even education for further studies, certainly hoping that there will be human development in the future where the quality of human resources will be better in the future. However, this PP has not clearly explained the limits between investment costs and others. Because it is possible for a fee to be spent to invested or it could be a liability. Take the building of the hall building, on the side, this can be an investment when it can be leased, but on the other hand it can be an obligation. The obligation here is related to the cost of arranging the hall, electricity, repairs if damage and so forth. In this regulation there has not been a detailed set of restrictions on this matter.

Furthermore, the costs that become another component are personal costs. Through PP No. 19 of 2005 also explained that personal costs are costs incurred by students to follow learning regularly and continuously. It is still not explained further what costs are included whether a monthly school fee, books or development costs. So that it will often be ambiguous which personal costs must be spent by the students.

\section{The Need for Educational Financing in Indonesia}

Looking at the exposure to the types of education funding above, surely there is a need for these types of education. This need can include the three policy provisions that have been decided by the government 
of course. Each category will have its own needs, because the purpose of each also exists.

Looking at the results of drop-out rates in Indonesia, the causes are mostly from inability to afford education from poor families. When compared with one type of financing, this can be included in personal financing. Seen from its nature, the lack of education costs due to this family background is included in personal financing. Viewed from the notion of personal costs according to PP No. 19 of 2005 which states that personal costs are costs incurred by students to be able to attend education in educational institutions. If the student does not have enough money to pay then he will not be able to continue his education directly. This is one of the forms of financing needs in Indonesia, namely the need for personal financing for each student. Looking at the causes of school dropout rates for poverty, this is similar to what Ferdy (2013) stated that the application of education funding still does not take full advantage of the middle and poor class.

In addition to personal costs, operational costs are also one of the needs needed by Indonesian education. Put a number of schools in several places that still do not have proper facilities and infrastructure to support the implementation of education. Based on this, school operational costs are a necessity in Indonesia. Reflecting on a phenomenon when there was a teacher in a school in Sumatra who drew ways to operate a computer on a blackboard became a clear proof of the lack of infrastructure in the school. So it is not wrong if the operational costs are actually still considered to be one of the financing needs for education in Indonesia. If both of these funds are still a burden for Indonesian education, then surely the investment costs are also not necessarily addressed. Personal and operational costs are the two basic financing in education funding, without these two financing education will not work well especially about investment financing, because new investments can be carried out if all needs have been met.

\section{Education Financing Policy in Indonesia}

The financing policy starts from the 1945 Constitution of the Republic of Indonesia (Amendment IV) that every citizen has the right to proper education and the government prioritizes the education budget of at least twenty percent of the State Budget (State Budget and Expenditure) (Fironika, 2015). Furthermore, the education fund is explained besides the educator's salary and the education fee is allocated at least $20 \%$ from the APBN and APBD while the salary of educators appointed by the government is taken from the APBN and APBD. This policy is the basis of education funding policies in Indonesia.

The policy in the 1945 Constitution was strengthened in Law No. 20 of 2003 concerning the national education system. In this law, it is reaffirmed about the implementation of national education. Article 11 explains that the government is obliged to guarantee the availability of education funds. This means that education funding is not entirely borne by students, but the government also takes part in these problems. Moreover, in this law, it is also stressed again that at least $20 \%$ of the APBN and APBD are budgeted for the costs of the education sector. Furthermore, based on Imron (2016) it was found that based on the Law of the Republic of Indonesia Number 2 of 1989 it was explained that the funding sources of education also came from the central government, regional governments, students to international grants. This funding source policy is the basis of financing policies in Indonesia.

Furthermore, in Government Regulation No. 19 of 2005 was also regulated on national education standards where in this PP it was regulated the types of education funding divided into three. Before being regulated in this PP, according to Fironika (2015), the Minister of National Education Decree had been issued on education Minimum Service Standards (SPM) through National Education Ministerial Decree No.53 /U/2001. In this decision it was stated that education MSS is a benchmark for the performance of education service delivery in provinces and districts/cities. This decision refers to Government Regulation No. 25 of 2000 concerning provincial authority as an autonomous region. This ministerial decree was later revised to Kepmendiknas No 129/U/2004 which was adjusted to the national education management system where non-formal education, youth, sports and early childhood education were highlighted.

Talking about operational costs can not be separated from what is known as School Operational Assistance (SOA/BOS in Indonesian). Guidelines for BOS are listed in the Minister of Education and Culture Regulation Number 8 of 2017 concerning Technical Guidelines for School Operational Assistance. However this regulation is revised again in the Minister of Education and Culture Regulation Number 26 of 2017 concerning Amendments to Minister of Education and Culture Number 8 of 2017 concerning Technical Guidelines for School Operational Assistance. Judging from the objectives based on this rule, it was found that BOS was used only to help school operational costs outside of the personal costs of students, although there 
were still some personal costs that could be paid through this BOS. With this BOS, the government aims to reduce dropout rates.

\section{Development of Education Financing Policies in} Indonesia

The education financing policy in Indonesia generally covers three types of financing; operational costs, investment costs, and personal costs. These three costs are considered to be the costs required to carry out education in Indonesia. Although not all three are borne by the government, the government still needs to pay attention to the three costs.

The government needs to pay attention to these three costs because based on its findings, Yoto (2012) revealed that there are still concerns for the Ministry of National Education in the distribution of $20 \%$ of the state budget in the education sector. This is because in 2008 the Ministry of National Education's financial report still obtained a disclaimer opinion. Of course this opinion will raise concerns about the distribution of education costs in Indonesia since it is possible that the distribution of education costs is not on the right target.

Looking at the existing regulations and policies, the direction of government policy has been included in the aim of alleviating compulsory education and helping finance education in Indonesia. This is proved by the launching of BOS to assist school operational costs. However, some confucion arise regarding to tha policies, as in PP No. 19 of 2005 in article 62 the scope of education standards is still ambiguous and unclear (Fironika, 2015). Thus, even though the policy direction has begun to be appropriate, it seems that there must still be a variety of studies on existing regulations and policies.

Policies released by the government should be truly in accordance with the needs of the people. If operational assistance has been rolled out, personal assistance is still needed. Since the dropout rate is so high, other financing is also needed. Investment policy arrangements should also be emphasized. With this investment policy setting, educational institutions will be able to continue. Investment cannot be seen now but the results can be enjoyed later. Such policy arrangements will make many institutions continue to survive and even develop.

\section{Conclusion}

Based on the explanation above, it can be concluded that the education financing policy in Indonesia continues to grow, from only stipulates the type of funding developed in the technical management of the National Budget for the world of education and up to the provision of operational assistance for schools. This development is of course adapted to the development of Indonesia's educational needs.

Although the policy continues to grow and is expected to be in accordance with the development of needs, in fact the dropout rate is still high. This high dropout rate is caused by economic factors. Based on this, the financing policy is still not integrated between financing education and financing for the assistance of the poor.

Some of these things can also be due to the ambiguous law matters. The policy is sometimes written quite clearly but does not specifically regulate the existing problems. As a result, the policy that exists is only a description of the problem but has not yet arrived at a solution to the problem and even the limitation of the problem is not clear.

\section{Suggestion}

Through this, the government should continue to review all kinds of education financing policies. The review can be conducted in the form of mapping the needs to the finding the formulation of suitable education funding needs in Indonesia. With the formulation of suitable needs, a suitable policy can be formed. Policies that can accommodate the needs will increase the growth and quality of Indonesian education.

This article still has many flaws. This paper only covers a brief description of the development of financing in Indonesia. It will be better to carry out about an analysis of the need for financing and its correlation with education funding policies in Indonesia in further research.

\section{References}

Afandi, T. (2017). Bonus Demografi 2030-2040: Strategi Indonesia Terkait Ketenagakerjaan dan Pendidikan. Jakarta: Kementrian Perencanaan Pembangunan Nasional.

Effendy, M. (2017, Juli 31). Peraturan Menteri Pendidikan dan Kebudayaan No 26 Tahun 2017. Permendikbud No 26 Tahun 2017. Jakarta, DKI, Indonesia: Kementrian Pendidikan dan Kebudayaan Republik Indonesia.

Fironika, R. (2015). Pembiayaan Pendidikan Di Indonesia. Jurnal Pendidikan Dasar, 43-64. 
Heri. (2016, 09 10). newa: radio idola. Retrieved 10 29, 2018, from radio idola.com: https://www.radioidola.com/2016/angka-putussekolah-73-persen-pendidikan-perlu-berbenah/

Imron, M. J. (2016). Manajemen Pembiayaan Sekolah. Al-Ibrah, 69-93.

P., F. W. (2013). Pembiayaan Pendidikan: Suatu Kajian Teoritis. Jurnal Pendidikan dan Kebudayaan, 565578.

rhs. (2018, Juli 22). Okezone. Retrieved Oktober 16, 2018, from okezone.com: https://economy.okezone.com/read/2018/07/21/320 /1925559/indonesia-penduduk-terbanyak-nomor4-di-dunia-siapa-juaranya

Sinaga, D. (2017, 04 18). CNN Indonesia. Retrieved 10 29, 2018, from www.cnnindonesia.com: https://student.cnnindonesia.com/edukasi/20170417 145047-445-208082/tingginya-angka-putussekolah-di-indonesia/

Sutrisnowati, S. A., \& Hadi, B. S. (2002). Tantangan Sumber Daya Manusia Di Era Global. Jurnal UNY, 55-64.

Yoto. (2012). Analisis Pembiayaan Pendidikan di Indonesia (Suatu Kajian Praktis Dalam Sistem Pengelolaan Anggaran Pendidikan Pada Sekolah Menengah Umum dan Kejuruan). Jurnal Teknik Mesin. Tahun 20, 78-93.

Yudhoyono, S. B. (2005, Mei 16). Peraturan Pemerintah Republik Indonesia No 19 Tahun 2005. Peraturan Pemerintah Republik Indonesia No 19 Tahun 2005 Tentang Standar Nasional Pendidikan. Jakarta, DKI, Indonesia: Kementrian Hukum dan Hak Asasi Manusia.

Yudhoyono, S. B. (2013, Mei 07). Peraturan Pemerintah No 23 Tahun 2013. Peraturan Pemerintah No 23 Tahun 2013 Tentang Perubahan Atas Peraturan Pemerintah Nomor 19 tahun 2005 Tentang Standar Nasional Pendidikan. Jakarta, DKI, Indonesia: Kementrian Hukum dan Hak Asasi Manusia. 